\title{
COVID-19 Related Coagulopathy: A Distinct Entity?
}

\author{
Benjamin Marchandot ${ }^{1}\left(\mathbb{D}\right.$, Laurent Sattler ${ }^{2}{ }^{(}$, Laurence Jesel ${ }^{1,3}$, Kensuke Matsushita ${ }^{1,3}{ }^{(0)}$, \\ Valerie Schini-Kerth ${ }^{3}{ }^{1}$, Lelia Grunebaum ${ }^{2}$ and Olivier Morel ${ }^{1,3, *}$ \\ 1 Université de Strasbourg, Pôle d'Activité Médico-Chirurgicale Cardio-Vasculaire, Nouvel Hôpital Civil, \\ Centre Hospitalier Universitaire, 67000 Strasbourg, France; benjaminmarchandot@gmail.com (B.M.); \\ Laurence.JESEL-MOREL@chru-strasbourg.fr (L.J.); matsuken_22@yahoo.co.jp (K.M.) \\ 2 Université de Strasbourg, Pôle de Biologie, Département d'Hémostase, \\ Centre Hospitalier Universitaire, 67000 Strasbourg, France; laurent.sattler@chru-strasbourg.fr (L.S.); \\ lelia.grunebaum@chru-strasbourg.fr (L.G.) \\ 3 UMR INSERM 1260, Regenerative Nanomedicine, Faculté de Pharmacie, Université de Strasbourg, \\ 67400 Illkirch, France; valerie.schini-kerth@unistra.fr \\ * Correspondence: olivier.morel@chru-strasbourg.fr; Tel.: +33-3695-50949
}

Received: 28 April 2020; Accepted: 26 May 2020; Published: 31 May 2020

\begin{abstract}
The coronavirus disease 2019 (COVID-19) pandemic has impacted healthcare communities across the globe on an unprecedented scale. Patients have had diverse clinical outcomes, but those developing COVID-19-related coagulopathy have shown a disproportionately worse outcome. This narrative review summarizes current evidence regarding the epidemiology, clinical features, known and presumed pathophysiology-based models, and treatment guidance regarding COVID-19 coagulopathy.
\end{abstract}

Keywords: coronavirus disease 2019; COVID-19; thrombosis; hemostasis; microparticles; endothelium; antiphospholipid antibodies

\section{Introduction}

Since December 2019, the coronavirus disease 2019 (COVID-19) has spread globally, infecting more than 3 million people and causing more than 213,273 deaths in over 200 countries as of 28 April 2020 [1-3]. Whereas COVID-19 is primarily a respiratory infection caused by severe acute respiratory syndrome coronavirus 2 (SARS-CoV-2), it has important systemic effects on the cardiovascular and immune systems [4,5]. COVID-19 patients present with a variety of phenotypes that range from asymptomatic to profound rapid multiple-organ dysfunction syndrome and death. Early reports of critically ill patients demonstrated that the development of coagulopathy was one of the most significant poor features [6,7], leading to a prompt response from both national and international societies of thrombosis and hemostasis to guide recognition and management of COVID-19-related coagulopathy [8-14]. A variety of potential risk factors for thrombosis have been proposed, including severe hypoxemia, inflammation, and endothelial dysfunction, on top of well-known features such as immobilization, respiratory failure, mechanical ventilation, and central venous catheter use: Hallmarks of critically ill patients.

This narrative review summarizes current evidence regarding the epidemiology, clinical features, known and presumed pathophysiology-based models, and treatment guidance regarding COVID-19 coagulopathy.

\section{Pathogenesis of COVID-19}

SARS-CoV-2 was initially identified in Wuhan, China in December 2019 [15]. A member of the Coronaviridae family, SARS-CoV-2 is an enveloped virus with non-segmented, single-stranded, 
positive-sense RNA genome [16,17]. SARS-CoV-2 binds its viral spike (S) proteins to angiotensin-converting enzyme 2 (ACE2) proteins for cell entry and uses the cellular serine protease transmembrane protease serine 2 (TMPRSS2) for S protein priming [17-20].

ACE2 is highly expressed in lung alveolar cells (principally type II alveolar cells) and serves a role in lung protection, and therefore viral binding to this receptor deregulates a lung protective pathway, contributing to viral pathogenicity [21,22]. Other significant locations comprise endothelial cells of blood vessels and the heart, pericytes, adipocytes, and neural cells [23]. The virus is thought to spread mainly from human to human through respiratory droplets produced by infected individuals [24]. Rapid spread has been related to (i) a similar detected viral load in symptomatic and asymptomatic patients with COVID-19, (ii) a high transmission as a large number of patients carry no or mild symptoms, and (iii) a basic reproduction number (R0) estimated to be $2.2[25,26]$. Initial symptoms of COVID-19 are non-specific and include fever, cough, shortness of breath, headaches, myalgias, diarrhea, and fatigue $[15,16]$. Large case series from China including 72,314 patients with COVID-19 have indicated that the clinical severity was mild (no or mild pneumonia) in $81 \%$, severe (dyspnea, respiratory frequency $\geq 30 / \mathrm{min}$, blood oxygen saturation $\leq 93 \%$, partial pressure of arterial oxygen to fraction of inspired oxygen ratio $<300$, and/or lung infiltrates $>50 \%$ within 24 to $48 \mathrm{~h}$ ) in $14 \%$, and critical (respiratory failure, septic shock, and/or multiple organ dysfunction or failure) in $5 \%$ of the population [27].

\subsection{Hemostasis Parameters in COVID-19}

The first hint of a noxious impact and frequent feature of hemostasis disorders in patients with novel coronavirus pneumonia was reported by Guan et al. on 28 February 2020 [6]. In this initial cohort of 1099 hospitalized patients with COVID-19, 46.4\% presented with an increased D-Dimer level above $0.5 \mathrm{mg} / \mathrm{L}$. A higher D-Dimer level was evidenced among severe compared to non-severe COVID-19 patients (59.6\% vs. $43.2 \%$, respectively) as for the occurrence of a primary composite end-point including intensive care unit (ICU) admission, invasive mechanical ventilation requirement, and death. Later reports of critically ill patients with abnormal coagulation parameters confirmed poor prognostic features $[7,28,29]$. In a cohort of 191 hospitalized patients with COVID-19, non-survivors had D-Dimer levels on admission greater than $1 \mathrm{mg} / \mathrm{L}$ in $81 \%$ ( $81 \%$ vs. $24 \%, p<0.0001$ ) [28]. Additionally, this threshold predicted an 18-fold increase in the odds of dying. Of note in this report, severe thrombocytopenia $<100 \times 109 / \mathrm{L}$ only occurred in $20 \%$ of non-survivors, similarly to prolonged prothrombin time (PT) $\geq 16 \mathrm{~s}$ in 13\%. Finally, a third study from China by Tang et al. [7] confirmed higher D-Dimer levels (2.12 vs. $0.61 \mu \mathrm{g} / \mathrm{mL}, p<0.001)$ and a mild increase in PT (15.5 vs. $13.6 \mathrm{~s}, p<0.001)$ in non-surviving patients. In this study, early increased fibrinogen and slightly decreased antithrombin levels did not reach statistical significance between survivors and non-survivors. Following early reports, the body of evidence now suggests that moderate and severe COVID-19 patients are likely to present prolonged PT, activated partial thromboplastin time (aPTT), and elevated D-Dimer levels with subsequent poorer outcomes [30-33].

\subsection{Disseminated Intravascular Coagulation in COVID-19}

Tang et al. reported that $71.4 \%$ of non-survivors and $0.6 \%$ of survivors showed evidence of disseminated intravascular coagulation (DIC), suggestive of a frequent manifestation with severe COVID-19 [7]. The pathophysiology of DIC in the setting of sepsis and acute respiratory distress syndrome (ARDS) is multifactorial and involves a complex interplay between cellular and plasmatic elements of the hemostatic system with immune-mediated exhaustion of the coagulation and fibrinolytic systems promoting bleeding and thrombosis in the same patient [34-36]. Severe infections and sepsis are a leading cause of DIC, and the pro-inflammatory and immune activation observed in severe COVID-19 is likely sufficient to trigger DIC. Such involvement of the hemostatic system in severe novel coronavirus pneumonia surprised the intensive care and hemostasis community due to the high likelihood to develop DIC [37]. Indeed, the frequency of DIC in COVID-19 patients is much higher 
than that reported for severe SARS with a total of $2.5 \%$ of SARS patients showing evidence of DIC [38]. As the COVID-19 pandemic keeps on progressing, additional studies are warranted to investigate the incidence of DIC and address the propensity of SARS-CoV-2 to engage both innate immune and hemostatic systems.

\subsection{D-Dimer Generation in COVID-19: Different Pathways?}

Physicians at the front line in the fight against the COVID-19 disease reported early concerns about markedly elevated D-Dimer levels: Are they any different from previous studies or similar conditions? Comparing the coagulation parameters between severe pneumonia induced by SARS-CoV-2 and non-SARS-CoV-2, Yin et al. reported in a retrospective analysis a higher platelet count $(215 \pm 100$ vs. $188 \pm 98, p<0.015)$ but no differences regarding other coagulation parameters including PT and D-Dimer [39]. This analysis was restricted to severe novel coronavirus pneumonia patients admitted to the intensive care unit, and unpublished data still indicate unusual higher levels of D-Dimers even in mild to moderate COVID-19 patients.

Hemostatic changes and high D-Dimer levels in COVID-19 patients have been explained by (i) excess thrombin generation and early fibrinolysis shutdown secondary to endothelial activation induced by the infectious trigger [40-42], (ii) severe hypoxemia known to stimulate thrombosis through both increased blood viscosity and hypoxia-inducible transcription factors [43], and finally (iii) local pulmonary thrombotic phenomena with a high frequency of pulmonary micro-thrombosis in small autopsy series $[44,45]$. Such focal thrombotic lung injury paved the way for the concept of a focal pulmonary thrombosis phenomenon in 2019 novel coronavirus pneumonia [46].

\subsection{Gaps in Evidence}

Since the initial description of COVID-19 abnormal coagulation parameters associated with poor prognosis, COVID-19 has been associated with noteworthy hemostatic features. First thought to mimic DIC, reports showed less prominent thrombocytopenia and consumption of coagulation proteins. No data have yet focused on thrombotic microangiopathy, and new research is warranted to assess a potential interaction between COVID-19, Von Willebrand, and ADAMTS-13. As most papers have concentrated mainly on thrombin generation to account for the hypercoagulability of COVID-19, SARS-CoV-2-induced platelet hyper-reactivity deserves deeper attention [47]. In addition to thrombosis and hemostasis, emerging evidence indeed supports a putative role of platelets in host defence against infections [48]. As the angiotensin-converting enzyme (ACE2) is also expressed in hepatic tissues, viral binding to a hepatic receptor may trigger liver dysfunction [49]. Finally, the role for antiphospholipid antibodies (see below) and immune thrombocytopenia in COVID-19-related thrombosis requires further investigation $[50,51]$.

\section{Pathophysiology of COVID-19-Induced Coagulopathy}

Higher thrombotic burden in the acute phase of COVID-19 relies on a complex interplay between pro-inflammatory cytokine/chemokine release, increased endothelial dysfunction/damage, and potential sepsis-induced coagulopathy development in severe cases, all promoting coagulation activation. The surprising highly pro-thrombotic features of COVID-19 seem to hail from (i) severe and prolonged hypoxemia known to stimulate thrombosis, (ii) high incidence of cytokine storms in critically ill patients, and finally (iii) a putative role of local pulmonary thrombotic phenomena.

\subsection{Inflammation}

Inflammation has been accepted as a common pathway through which various risk factors trigger thrombogenesis $[52,53]$. Cytokines and chemokines have been associated with an important role in immunity and immunopathology during viral infections [54-56]. The immune response to acute SARS-CoV-2 infection and the accompanying surge of cytokines and inflammatory mediators (interleukin (IL)-6, IL-7, IL-22, C-x-C motif chemokine 10, etc.) can lead to activating pro-coagulant 
pathways. Inflammatory cytokines, together with endothelial injury, can up-regulate tissue factor expression and further drive a pro-thrombotic state [37,57]. In coronary arteries, circulating cytokines can stimulate macrophages within the plaque to increase local cytokine production and provoke tissue factor overexpression that renders lesions more thrombogenic. This mechanism of a local, intraplaque response to systemic stimuli was referred to as an "echo" phenomenon by Libby [58]. Systemic cytokines can stimulate leukocyte adhesion molecule expression on the endothelial cells overlying established atheroma, boosting local recruitment of these inflammatory cells [58].

Early reports from China described severely elevated levels of inflammatory biomarkers and cytokines such as IL-6, IL-1 $\beta$, C-reactive protein, Tumor necrosis factor (TNF)-alpha, granulocyte-colony stimulating factor, and ferritin [15,28,59,60]. Advanced stages of COVID-19 have been linked to cytokine storm syndromes and identified patients at higher risk of progressing to severe diseases including DIC, acute myocardial injury due to myocarditis or stress-cardiomyopathy, and death [61-63]. Siddiqi et al. have proposed a schema to assess the severity of "systemic hyperinflammation" in COVID-19 [64].

According to this paradigm, the host response to COVID-19 is first localized in the lung parenchyma, but a systemic surge in pro-inflammatory cytokines can occur. Defined as a "cytokine storm," the incidence, role, and specific involvement of cytokine storms is yet to be addressed in SARS-CoV-2, and its interactions with hemostatic changes as observed in previous viral diseases [65-67] remain to be established.

\subsection{Endothelial Activation}

Clinical and pre-clinical evidence supports the hypothesis that the endothelium is a key target organ of COVID-19 [68,69]. The importance of the endothelium in the pathogenesis of COVID-19 infection was recently emphasized by data demonstrating direct endothelial cell infection and endotheliitis in the time course of SARS-CoV-2 infection [70]. In humans, the angiotensin-converting enzyme 2 (ACE2) receptor has been found in the lung epithelium (in particular the type II pneumocyte) and the myocardium, and is highly expressed in arterial and venous endothelial cells [71]. Endothelial cell activation/damage due to the virus binding to the ACE2 receptor promoting acute inflammation and hypercoagulation may be of paramount importance to explain the high thrombotic burden observed.

Under physiological conditions, pulsatile shear stress increased ACE2 expression, promoting nitric oxide production, and reducing inflammation and proliferation in vascular endothelial cells [72]. The recent description of higher ACE2 expression as determined by RNA sequencing and confirmed by proteomic profiling in heart muscle disease patients might explain why heart failure patients could be more vulnerable to heart infection by SARS-CoV-2 [23]. Pericytes, which spread outside the endothelial cell of capillaries and parts of venules, were also suggested to be a key target in SARS-CoV-2 infection and might explain the importance of capillary endothelial cell dysfunction and microcirculation disorder in that setting [23]. General mechanisms of endothelial activation following a cytokine burst include calcium mobilization, oxidative stress, down-regulation of the endothelial nitric oxide synthase-derived nitric oxide formation, plasma membrane remodeling, exposure of procoagulant phospholipid such as phosphatidylserine, procoagulant microparticles (MPs) shedding, tissue factor expression, disruption of the natural anticoagulant shield represented by annexin 5 , expression of selectins and cytoadhesins (vascular cell adhesion molecule 1, intercellular adhesion molecule 1), and cytokines release (monocyte chemoattractant protein-1). Within pulmonary microvascular endothelial cells, exposure to various inflammatory stimulus (TNF-alpha, lipopolysaccharide) induced the release of endothelial-derived MPs (EMPs), harbouring ACE and a simultaneous decrease of endothelial cell-surface ACE expression [73]. In a mouse model of lung injury, $\mathrm{ACE}^{+}$-EMPs/EMPs were evidenced to be a marker of wet-to-dry lung injury as a possible witness of alveolar capillary barrier alterations. In sepsis, the importance of these findings was emphasized by the demonstration of elevated levels of $\mathrm{ACE}^{+}$-EMPs and $\mathrm{ACE}^{+}$-EMPs/EMPs in the blood of patients who developed ARDS [73]. 
Finally, endothelial cell activation/damage due to the virus binding to the ACE2 receptor promoting acute inflammatory and hypercoagulable may be of paramount importance to explain the high thrombotic burden observed [70].

\subsection{Severe Hypoxemia}

Gathering experience from Chinese and Italian physicians at the front line in early phases of the COVID-19 pandemic, much attention has been paid to hypoxemia. Indeed, "silent hypoxemia" has been described in many COVID-19 patients. Patients were hypoxemic as they may have had an oxygen saturation of about $80 \%$ room air, but clinically looked comfortable, and not dyspneic or tachypneic. Complementary reports reinforce the high frequency and noxious impact of severe hypoxemia [74-76]. ARDS occurred in approximately 40\% of 201 patients with 2019 novel coronavirus pneumonia [29]. The COVID-19 pneumonia has lately been addressed as a specific disease with peculiar phenotypes. Its main characteristic is the dissociation between the severity of the hypoxemia and the maintenance of relatively good respiratory mechanics [77].

Severe lung inflammation and impaired pulmonary gas exchange in COVID-19 can stimulate thrombosis through a hypoxia-inducible transcription factor-dependent signaling pathway [43]. Furthermore, hypoxia, and ARDS in particular, is known to promote hypoxic pulmonary vasoconstriction and pulmonary hypertension, increase right ventricular afterload, and favor blood viscosity.

\subsection{Pulmonary Microvascular Thrombosis}

Focal microvascular thrombosis and pulmonary emboli in a small autopsy series have recently been reported $[44,45]$. Such focal thrombotic lung injury paved the way for the concept of a focal pulmonary thrombosis phenomenon in 2019 novel coronavirus pneumonia [46]. The entry receptor utilized by SARS-CoV is ACE2, which is highly expressed in lung alveolar cells, principally type II alveolar cells. High pulmonary viral loads in the alveoli of COVID-19-infected patients have been reported [78]. The primary infection initiates alveolar injury, resulting in a local inflammatory response, and these microvascular thrombi have been described in an environment of marked inflammatory changes including mononuclear cell infiltrates, virally infected cells, and diffuse alveolar damage [79]. The key question relies upon whether ARDS and/or DIC lead to pulmonary microvascular thrombi on one hand, and, on the other hand, whether focal pulmonary microthrombi can lead to further hypoxemic respiratory failure, enhanced thrombo-inflammation, and hypercoagulability with ARDS and DIC as final consequences: Both options are likely. It may be hypothesized that lung injury results in microthrombus formation further enhanced in the setting of a hypercoagulable state like DIC.

In this paradigm, the shedding of $\mathrm{ACE}^{+}$-MPs by lung microvascular endothelial cells could be of paramount importance [73].

Marongiu et al. developed the view of a "pulmonary thrombosis in 2019 novel coronavirus pneumonia" [46]. The authors emphasized the view of a prothrombotic pulmonary endothelial dysfunction, causing a severe acute inflammation via complement and cytokine release, and a blood coagulation activation with vascular microthrombosis that further induces a local consumption coagulopathy, i.e., a DIC, resulting in ARDS. In light of the Marongiu suggestion that anticoagulant treatment may be helpful by limiting the vicious circle of inflammation-blood coagulation activation-inflammation, thus improving the severely impaired gas exchange in these patients, Rannuci et al. [80] recently showed that the use of an increased dose of low-molecular-weight heparin (LMWH) appeared to reduce the downstream thrombotic effects of the marked inflammatory response to COVID-19 as it seems to decrease the contribution of microvascular thrombosis in severely hypoxemic COVID patients. 


\section{Coagulopathy Disorders Disease in COVID-19 Patients}

In line with previous insights from the SARS and A-H1N1 experiences [81,82], data from 1026 patients with COVID-19 in the Chinese population assumed that $40 \%$ of patients at the time of hospital admission were considered at high venous thromboembolic (VTE) risk on the basis of a Padua Prediction Score $\geq 4$ [83].

\section{Prevalence of Venous Thromboembolic Disease in COVID-19}

While a number of studies have shown that coagulation dysfunction is preponderant in patients with severe novel coronavirus pneumonia, only a few studies in the available literature have focused on the prevalence of VTE in COVID-19 patients. Early case reports [84-86] reporting deep vein thrombosis and/or acute pulmonary embolism (APE) paved the way for a more comprehensive insights into VTE events in larger cohorts. The first retrospective registry cohort of 25 APE-suspected COVID-19 patients in China with computed tomography pulmonary angiography showed that those with confirmed APE $(n=10)$ had D-Dimer levels higher than $7000 \mathrm{ng} / \mathrm{mL}$ [87]. In 91 hospitalized patients with severe COVID-19, VTE patients accounted for 25\%, were older, and showed increased coagulopathy abnormalities and thrombotic susceptibility (lower lymphocytes count, longer aPTT, and higher D-Dimer levels). In this study proposed by Ciu et al. [88], a D-Dimer cut-off value $\geq 1.5 \mu \mathrm{g} / \mathrm{mL}$ was associated with a sensitivity, specificity, positive predictive value, and negative predictive value of $85.0 \%, 88.5 \%, 70.8 \%$, and $94.7 \%$, respectively. Moreover, Klok et al. reported a $31 \%$ incidence of thrombotic complications despite systematic thrombosis prophylaxis and no DIC development among a cohort of 184 ICU patients [89]. Similarly, age and coagulopathy defined as spontaneous aPTT time > $5 \mathrm{~s}$ (HR 4.1, 95\% CI 1.9-9.1) were independent predictors of thrombotic complications.

Finally, Helms et al. lately reported an incidence of $42.6 \%$ of thrombotic complications, mainly APE (16.7\%) in 150 COVID-19 patients admitted in ICU for hypoxemic acute respiratory failure [90]. Twenty-eight out of twenty-nine patients $(96.6 \%)$ receiving continuous renal replacement therapy experienced circuit clotting, and three thrombotic occlusions of centrifugal pump occurred in 12 patients supported by extracorporeal membrane oxygenation. Most patients ( $>95 \%)$ had elevated D-dimer levels and fibrinogen, while no patient developed disseminated intravascular coagulation. Most importantly, despite anticoagulation, patients with ARDS secondary to COVID-19 developed significantly more thrombotic complications compared to non-COVID-19 ARDS patients ( $11.7 \%$ vs. $2.1 \%, p<0.008)$. The authors proposed in their discussion appealing mechanisms of coagulopathy and pathogenesis of thrombosis in severe hypoxemic COVID-19 patients. They underlined the paramount importance of (i) obvious endothelial inflammation with very high levels of Von Willebrand factor antigen and factor VIII, (ii) hypotheses regarding profound hypoxemia in the pulmonary capillaries that may result in vasoconstriction reducing blood flow and promoting vascular occlusion, and finally (iii) the intriguing high frequency of positive lupus anticoagulant that was detected in 50 patients out of the 57 tested $(87.7 \%)$.

Altogether, the increased presence of VTE holds true for COVID-19 patients, most notably among those with severe disease. Currently, the mechanism of these associations remains to be fully characterized.

\section{Antithrombotic Therapy and COVID-19-Related Coagulopathy}

\subsection{Current Recommendations}

Following initiatives from national scientific academies [8-12], the International Society of Thrombosis and Haemostasis (ISTH) promptly proposed an interim guidance on recognition and management of coagulopathy in COVID-19 on 25 March, 2020 [13].

In line with coagulation markers at admission and follow up, the provided statement reinforced the need for a risk stratification for all COVID-19 patients including D-Dimers, PT, and platelet count, as these biological parameters are likely to help in stratifying patients who may need admission and close 
monitoring. As recommended by the previous ISTH guidance [91], regular monitoring of hemostatic markers in critical care units is likely to include fibrinogen on top of platelet count, PT, and D-Dimers as it may detect early DIC development, determine prognosis, and guide critical care support.

Regarding antithrombotic options, the ISTH consensus statement recommended prophylactic dose low-molecular weight heparin (LMWH) in all patients (including non-critically ill) who required hospital admission for COVID-19 infection, in the absence of any contraindications (active bleeding and/or platelet count less than $25 \times 109 / \mathrm{L})$ [13].

\subsection{Heparin and COVID-19}

Heparin therefore represents the optimal thrombo-prophylactic and antithrombotic regimen endorsed by contemporary guidelines for patients hospitalized with COVID-19 related illnesses [13]. Tang et al. described that anticoagulant therapy mainly with LMWH appeared to be associated with a better prognosis in 449 severe COVID-19 patients meeting sepsis induced coagulopathy (SIC) criteria $\geq 4$ or with markedly elevated D-Dimer levels (greater than six-fold at the upper limit of normal) [92]. In this paper, however, only 99 patients $(22 \%)$ had received prophylactic heparin. Heparin therapy has several advantages: (i) It represents, in the time of a pandemic, an easily available anticoagulant therapy, given the initial concerns regarding drug shortages [93]; (ii) incremental anti-inflammatory effects have been reported [94] and it may mitigate cytokine storms in severe COVID-19 patients [95]; (iii) experimental models reported a potential antiviral role of heparin $[96,97]$ still to be confirmed in clinical practice and in the setting of SARS-CoV-2 infection; and finally (iv) there is currently no evidence from randomized clinical trials that any potential therapy improves outcomes in patients with either suspected or confirmed COVID-19 [98]. Given the high prevalence of lupus anticoagulant and changes of standard hemostasis parameters in this particular pathology, monitoring of heparin should not rely on aPTT, but solely on anti-Xa activity.

In summary, a substantial body of evidence suggests how heparin can be beneficial in selected high-risk COVID-19 patients. Conversely, much less is known regarding ambulatory COVID-19 patients' management and extended thromboprophylaxis after hospitalization.

\subsection{Gaps in Evidence}

Since the clinical experience of managing COVID-19 patients is still limited, gaps remain in the evidence for the management of COVID-19-related coagulopathy. Real incidence of VTE remains unknown in the sparse literature and is probably underestimated because of asymptomatic presentation and/or the lack of systematic imaging. Indeed, routine imaging according to a defined D-Dimer threshold has been proposed in some medical facilities such as ours (arbitrarily greater than ten-fold at the upper limit of normal). Similarly, higher than prophylactic doses of LMWH in those with either (i) extremely high D-Dimer levels at admission, (ii) higher levels of ventilation, or (iii) presenting with ARDS, have been proposed [99]. Validated factors, such as a lack of mobility, advanced age, cancer, previous venous thromboembolism, and elevated D-Dimer levels ( $>2$ upper the limit of normal range) have been previously associated in the identification of patients who are at risk for symptomatic venous thromboembolism [100]. In the light of a proinflammatory and procoagulant state in COVID-19 patients, extending the research based on previous prolonged thromboprophylaxis experiences in acute medically ill patients may be of particular interest [101-104].

As the coronavirus outbreak overwhelmed healthcare capacities in some regions, most patients presenting with mild-to-moderate forms have been managed with "home care", despite ISTH recommendations for hospitalization of patients presenting with three- to four-fold increase of D-Dimers [13]. Therefore, thromboprophylaxis guidance for ambulatory COVID-19 patients is urgently needed. Mirroring prior trials such as the MARINER initiative [104], studies testing either extended thromboprophylaxis after hospitalization or ambulatory thromboprophylaxis in selected COVID-19 patients with direct oral anticoagulants may be of particular interest. 
Finally, in vitro studies aimed to define anti-inflammatory properties and viral inhibition of heparin in the field of COVID-19 represent an appealing subject for future research. Extended reports from tissue plasminogen activator treatment is required [105]. Bleeding seems either rare or under-reported in the setting of COVID-19 and deserves further insights. Finally, the current published COVID-19 experience does not detail the incidence of arterial thrombosis events (stroke, acute coronary syndromes, etc.).

\section{Future Research}

\subsection{A Role for Obesity}

A high proportion of older patients in a predominantly male population with cardiovascular disease and cardiovascular risk factors have been considered the main determinant of the increased morbidity and mortality [4]. Obesity has recently been increasingly recognized as a major risk factor for severe COVID-19 disease [106-108]. Of note, it has long been recognized as a major risk factor for hospitalization and mechanical ventilation [109]. Adipose tissue, besides its role in energy storage, is a potent source of hormones, peptides, procoagulant MPs [110], and cytokines, known as adipokines, and was recently described as an important reservoir of ACE2 [23]. Adipose tissue is involved in the regulation of inflammation (e.g., TNF-alpha, IL-6, macrophage chemo attractant protein-1) and thrombosis (e.g., plasminogen activator inhibitor-1) [111,112]. Since adipose tissue is known to induce an inflammatory state, the potential link between obesity and COVID-19 coagulopathy deserves further insights. Indeed, metabolic syndrome on a broader scale is a hallmark of a pre-existing inflammatory state that may be a necessary condition and/or amplified by COVID-19 in the development of a pro-thrombotic state. The intimated interplay between obesity and COVID-19 severity deserves further insights.

\subsection{Possible Role of Microparticles in the Development of COVID-19-Induced Coagulopathy}

In the time course of COVID-19 infection, it is likely that the cytokine storm promotes a strong activation of circulating blood cells including platelets and leukocytes, and also of endothelial cells lining the luminal surface of the vasculature (Figure 1). This activation process leads to cell blebbing with the shedding of microparticles (MPs) into the circulation. These MPs harbor a mixture of membrane proteins similar to those of the cell membrane of origin, and carry proteins and miRNA to transmit the activator signal to distant cells following cell-cell interaction, thereby contributing to the propagation of the disease. The target cell activation and the circulating MPs promote pro-coagulant responses due to the exposure of tissue factor, and the physiological activator of the coagulation cascade and of negatively-charged phospholipids such as phosphatidyl serine, required for the establishment of the tenase and prothrombinase coagulation complexes ultimately leading to thrombin generation. In the context of cardiovascular disease patients, a vulnerable population in the time course of COVID-19 infection, elevated levels of procoagulant MPs were described in a variety of settings including arterial hypertension, diabetes mellitus, dyslipidemia, obesity, pulmonary embolism, arterial hypertension, acute coronary syndromes, heart failure, etc. [113]. In a large community-based Framingham Heart study, circulating endothelial MP levels were associated with the presence of cardiometabolic risk factors including hypertension and metabolic factors [114], known predisposing factors to severe COVID-19 infections. Recent investigations by our group have indicated that circulating MPs of patients with acute coronary syndrome (ACS-MPs), predominantly of activated endothelial cell and platelet origin, promote pro-oxidant, prothrombotic, and pro-inflammatory responses in endothelial cells leading to endothelial senescence and dysfunction [115]. The stimulatory effect of MPs involves the up-regulation of ACE, which in turn promotes a pro-oxidant response in endothelial cells. Moreover, the ACS-MPs were shown to carry ACE activity, suggesting that they originate predominantly from activated endothelial cells. Another report performed in microvascular lung endothelial cells and in ARDS patients has emphasized the importance of $\mathrm{ACE}^{+}$- endothelial-derived MPs as a possible marker 
of disease severity [73]. Although the presence of ACE2 was not specifically characterized in those studies, these data suggest that circulating MPs are key modulators of various ACE activities within the vascular compartment and could therefore act as an important mediator of COVID-19 pathogenicity. In the context of HIV infection, the transfer of the chemokine receptor between cells by membrane-derived MPs was also demonstrated to be a potent mechanism for cellular human immunodeficient virus 1 infection [116]. In line with this paradigm, recent data have highlighted that exosome, a subtype of extracellular microvesicles shed by endothelial progenitor cells, promotes survival and function of endothelial cells through ACE2 delivery [117]. Preliminary results in COVID-19 patients requiring hospitalization relate a 2 -fold generation of procoagulant MPs with respect to values measured in non-COVID-19 patients.

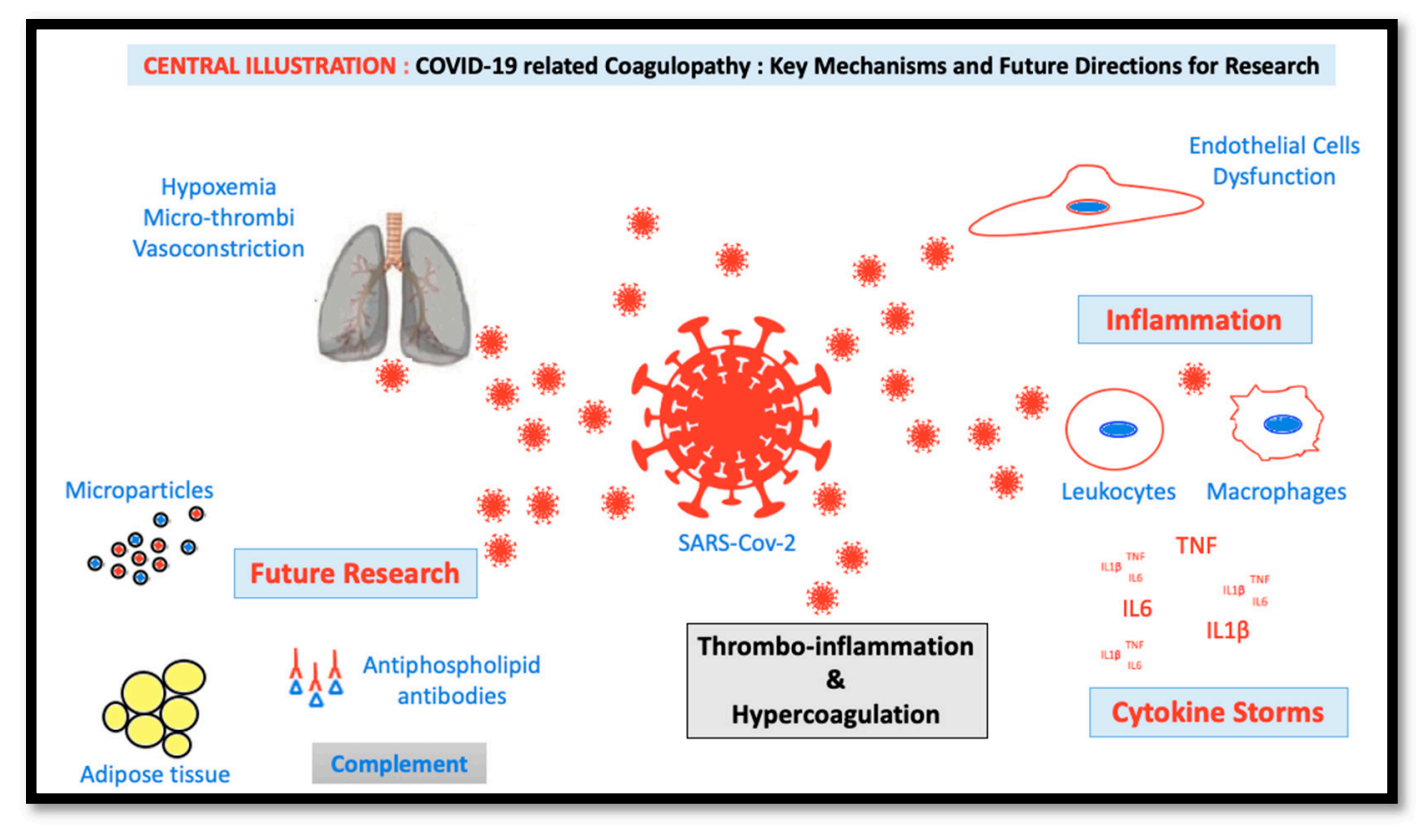

Figure 1. Conceptual figure highlighting major key mechanisms for COVID-19 coagulopathy and future directions in research.

\subsection{Antiphospholipid Antibodies in COVID-19 Patients}

The importance of antiphospholipid (aPLs) antibodies in the development of COVID-19 coagulopathy was stressed by the recent description of multi-cerebral infarctions in 3 patients with antiphospholipid antibodies that were characterized as anticardiolipin IgA, anti B2 glycoprotein I IgA, and IgG [50]. Probable mechanisms of thrombosis in antiphospholipid syndrome comprise endothelial cell dysfunction, platelet activation, complement system activation, inflammatory cell-mediated mechanisms, alteration of anticoagulant properties (tissue factor pathway inhibition, inhibition of the protein $C$ pathway, interference with the action of antithrombin), and reduced fibrinolysis (elevated PAI-1 levels, inhibition of plasminogen binding, and plasma activity) [118]. In our experience, among 150 patients hospitalized for COVID-19 in ICU, the presence of transient lupus anticoagulant (aPL having the ability to prolong clotting time in vitro) was detected in a vast majority of the cases $(87.7 \%)$ [90]. An inverse correlation between procoagulant MPs levels and aPL activity could be established, suggesting that parts of aPLs could be trapped by circulating MPs, therefore escaping to biological detection. The most important antigen for aPLs is b2-glycoprotein-I (b2GPI), a scavenger molecule, which has a specific binding site for the negatively-charged phospholipid phosphatidylserine (PS). Under physiological conditions, the binding to PS, b2-GPI facilitates clearance of particles and apoptotic bodies from the circulation enabling the maintenance of vascular homeostasis [119]. b2GPI in plasma is normally present as a circular protein; in the case of endothelial cell activation and subsequent remodeling, the exposure of PS at the outer leaflet of the plasma membrane induces conformational 
changes of b2GPI that "opens up" to a J shape, thus exposing neo epitopes and antibody-binding sites [119]. Membrane remodeling could also contribute to the alteration of natural anticoagulant shield represented by Annexin V, a protein with high PS affinity. Other reports by Nomura and Mobarrez have demonstrated that b2GPI binds preferentially to procoagulant PS-expressing MPs [120], rather than non-PS vesicles. PS-binding antibodies can form structures similar to immune complexes, which are likely to be cleared by Fc receptors through antibody-mediated phagocytosis, reinforcing systemic inflammation and complement activation.

\subsection{Complement Activation in COVID-19 Patients}

Other COVID insights have suggested that thrombotic microangiopathy could include pathogenic complement activation. Antibody-antigens complexes could trigger the classical pathway, inducing the production of $\mathrm{C} 3 \mathrm{a}$ and $\mathrm{C} 5 \mathrm{a}$ inflammatory markers. Data from murine models have suggested that in the case of the C3 defect, COVID-19 infection was decreased, as witnessed by the decrease of respiratory dysfunction and cytokines levels, despite equal virus loads [121]. Along this line, complement inhibition was suggested to be a promising treatment for severe COVID-19 by reducing the innate immune-mediated consequences of severe SARS-CoV-2 infections [122].

\section{Conclusions}

The relationship between COVID-19 and thrombogenesis seems deeply intricate, complex, and still little understood. Concerns and controversies have been raised towards a potential distinct "COVID-19-induced coagulopathy pattern", while softened statements share the view that it is only part of the well-known "sepsis-induced coagulopathy" or "disseminated intravascular coagulopathy". More research is needed to explore the interplay between the pulmonary and endothelial localization of ACE2 receptors, hypoxia, and pulmonary microthrombi. There are key elements to investigate in the field of the unique hypercoagulability and thrombo-inflammatory responses associated with COVID-19.

Author Contributions: Drafting of the manuscript, review, and editing, B.M.; drafting of the manuscript and critical revision for important intellectual content, L.S.; drafting of the manuscript, review, and critical revision for important intellectual content, L.J.; drafting of the manuscript, and critical revision for important intellectual content, K.M.; drafting of the manuscript, critical revision for important intellectual content, review, and editing, V.S.-K.; drafting of the manuscript, and critical revision for important intellectual content, L.G.; drafting of the manuscript, and critical revision for important intellectual content, review, editing, and supervision, O.M. All authors have read and agreed to the published version of the manuscript.

Conflicts of Interest: All the authors take responsibility for all aspects of the reliability and freedom from bias of the data presented and their discussed interpretation. All authors have read and approved the submission of the manuscript. The manuscript has not been published and is not being considered for publication elsewhere in whole or part in any language. The authors disclose any financial associations that might pose a conflict of interest in connection with the submitted article.

\section{References}

1. Chan, J.F.; Yuan, S.; Kok, K.H.; To, K.K.; Chu, H.; Yang, J.; Xing, F.; Liu, J.; Yip, C.C.; Poon, R.; et al. A familial cluster of pneumonia associated with the 2019 novel coronavirus indicating person-to-person transmission: A study of a family cluster. Lancet 2020, 395, 514-523. [CrossRef]

2. Dong, E.; Du, H.; Gardner, L. An interactive web-based dashboard to track COVID-19 in real time. Lancet Infect. Dis. 2020, 20, 533-534. [CrossRef]

3. COVID-19 Dashboard by the Center for Systems Science and Engineering (CSSE) at Johns Hopkins University (JHU). Available online: https://www.arcgis.com/apps/opsdashboard/index.html\# /bda7594740fd40299423467b48e9ecf6 (accessed on 28 April 2020).

4. Matsushita, K.; Marchandot, B.; Jesel, L.; Ohlmann, P.; Morel, O. Impact of COVID-19 on Cardiovascular System: A Review. J. Clin. Med. 2020, 9, 1407. [CrossRef] [PubMed]

5. Shi, Y.; Wang, Y.; Shao, C.; Huang, J.; Gan, J.; Huang, X.; Bucci, E.; Piacentini, M.; Ippolito, G.; Melino, G. COVID-19 infection: The perspectives on immune responses. Cell Death Differ. 2020,27,1451-1454. [CrossRef] 
6. Guan, W.J.; Ni, Z.Y.; Hu, Y.; Liang, W.H.; Ou, C.Q.; He, J.X.; Liu, L.; Shan, H.; Lei, C.L.; Hui, D.S.; et al. China Medical Treatment Expert Group for Covid-19. Clinical Characteristics of Coronavirus Disease 2019 in China. N. Engl. J. Med. 2020, 382, 1708-1720. [CrossRef]

7. Tang, N.; Li, D.; Wang, X.; Sun, Z. Abnormal coagulation parameters are associated with poor prognosis in patients with novel coronavirus pneumonia. J. Thromb. Haemost. 2020, 18, 844-847. [CrossRef]

8. Susen, S.; Tacquard, C.A.; Godon, A.; Mansour, A.; Garrigue, D.; Nguyen, P.; Godier, A.; Testa, S.; Albaladejo, P.; Gruel, Y.; on behalf of the GIHP and GFHT Group. Diagnosis and Management of Heparin-Induced Thrombocytopenia: Proposals from the French Working Group on Perioperative Haemostasis (GIHP) and the French Study Group on Thrombosis and Haemostasis (GFHT), in Collaboration with the French Society for Anesthesia and Intensive Care (SFAR). Available online: https://sfar.org/propositions-tih-gihp-gfht-sfar (accessed on 28 April 2020).

9. Shanghai Clinical Treatment Expert Group for COVID-19. Comprehensive treatment and management of coronavirus disease 2019: Expert consensus statement from Shanghai (in Chinese). Chin. J. Infect. 2020, 38. published online ahead of print.

10. Hunt, B.; Retter, A.; McClintock, C. Practical Guidance for the Prevention of Thrombosis and Management of Coagulopathy and Disseminated Intravascular Coagulation of Patients Infected with COVID-19. Available online: https://thrombosisuk.org/downloads/T\&H\%20and\%20COVID.pdf (accessed on 28 April 2020).

11. Marietta, M.; Ageno, W.; Artoni, A.; De Candia, E.; Gresele, P.; Marchetti, M.; Marcucci, R.; Tripodi, A. COVID-19 and haemostasis: A position paper from Italian Society on Thrombosis and Haemostasis (SISET). Blood Transfus 2020. [CrossRef]

12. Casini, A.; Alberio, L.; Angelillo-Scherrer, A.; Fontana, P.; Gerber, B.; Graf, L.; Hegemann, I.; Korte, W.; Kremer Hovinga, J.; Lecompte, T.; et al. Thromboprophylaxis and laboratory monitoring for in-hospital patients with Covid-19-a Swiss consensus statement by the Working Party Hemostasis. Swiss Med. Wkly. 2020, 150, w20247. [CrossRef]

13. Thachil, J.; Tang, N.; Gando, S.; Falanga, A.; Cattaneo, M.; Levi, M.; Clark, C.; Iba, T. ISTH interim guidance on recognition and management of coagulopathy in COVID-19. J. Thromb. Haemost. 2020, 18, 1023-1026. [CrossRef]

14. Bikdeli, B.; Madhavan, M.V.; Jimenez, D.; Chuich, T.; Dreyfus, I.; Driggin, E.; Nigoghossian, C.D.; Ageno, W.; Madjid, M.; Guo, Y.; et al. COVID-19 and Thrombotic or Thromboembolic Disease: Implications for Prevention, Antithrombotic Therapy, and Follow-up. J. Am. Coll. Cardiol. 2020. [CrossRef] [PubMed]

15. Zhu, N.; Zhang, D.; Wang, W.; Li, X.; Yang, B.; Song, J.; Zhao, X.; Huang, B.; Shi, W.; Lu, R.; et al. A Novel Coronavirus from Patients with Pneumonia in China, 2019. N. Engl. J. Med. 2020, 382, 727-733. [CrossRef] [PubMed]

16. Huang, C.; Wang, Y.; Li, X.; Ren, L.; Zhao, J.; Hu, Y.; Zhang, L.; Fan, G.; Xu, J.; Gu, X.; et al. Clinical features of patients infected with 2019 novel coronavirus in Wuhan, China. Lancet 2020, 395, 497-506. [CrossRef]

17. Driggin, E.; Madhavan, M.V.; Bikdeli, B.; Chuich, T.; Laracy, J.; Bondi-Zoccai, G.; Brown, T.S.; Nigoghossian, C.D.; Zidar, D.A.; Haythe, J.; et al. Cardiovascular Considerations for Patients, Health Care Workers, and Health Systems During the Coronavirus Disease 2019 (COVID-19) Pandemic. J. Am. Coll. Cardiol. 2020, 75, 2352-2371. [CrossRef]

18. Ge, X.Y.; Li, J.L.; Yang, X.; Chmura, A.A.; Zhu, G.; Epstein, J.H.; Mazet, J.K.; Hu, B.; Zhang, W.; Peng, C.; et al. Isolation and characterization of a bat SARS-like coronavirus that uses the ACE2 receptor. Nature 2013, 503, 535-538. [CrossRef]

19. Zhou, P.; Yang, X.L.; Wang, X.G.; Hu, B.; Zhang, L.; Zhang, W.; Si, H.R.; Zhu, Y.; Li, B.; Huang, C.L.; et al. A pneumonia outbreak associated with a new coronavirus of probable bat origin. Nature 2020, 579, $270-273$. [CrossRef]

20. Hoffmann, M.; Kleine-Weber, H.; Schroeder, S.; Kruger, N.; Herrler, T.; Erichsen, S.; Schiergens, T.S.; Herrler, G.; Wu, N.H.; Nitsche, A.; et al. SARS-CoV-2 Cell Entry Depends on ACE2 and TMPRSS2 and Is Blocked by a Clinically Proven Protease Inhibitor. Cell 2020, 181, 271-280.e8. [CrossRef]

21. Zhang, H.; Penninger, J.M.; Li, Y.; Zhong, N.; Slutsky, A.S. Angiotensin-converting enzyme 2 (ACE2) as a SARS-CoV-2 receptor: Molecular mechanisms and potential therapeutic target. Intensive Care Med. 2020. [CrossRef]

22. Xu, H.; Zhong, L.; Deng, J.; Peng, J.; Dan, H.; Zeng, X.; Li, T.; Chen, Q. High expression of ACE2 receptor of 2019-nCoV on the epithelial cells of oral mucosa. Int. J. Oral Sci. 2020, 12, 1-5. [CrossRef] 
23. Chen, L.; Li, X.; Chen, M.; Feng, Y.; Xiong, C. The ACE2 expression in human heart indicates new potential mechanism of heart injury among patients infected with SARS-CoV-2. Cardiovasc. Res. 2020, 116, 1097-1100. [CrossRef]

24. Centers for Disease Control and Prevention. Interim, U.S. Guidance for Risk Assessment and Public Health Management of Healthcare Personnel with Potential Exposure in a Healthcare Setting to Patients with Coronavirus Disease (COVID-19). Available online: https://www.cdc.gov/coronavirus/2019-ncov/hcp/ guidance-risk-assesment-hcp.html (accessed on 9 April 2020).

25. Zou, L.; Ruan, F.; Huang, M.; Liang, L.; Huang, H.; Hong, Z.; Yu, J.; Kang, M.; Song, Y.; Xia, J.; et al. SARS-CoV-2 Viral Load in Upper Respiratory Specimens of Infected Patients. N. Engl. J. Med. 2020, 382, 1177-1179. [CrossRef] [PubMed]

26. Peiris, J.S.; Chu, C.M.; Cheng, V.C.; Chan, K.S.; Hung, I.F.; Poon, L.L.; Law, K.1.; Tang, B.S.; Hon, T.Y.; Chan, C.S.; et al. Clinical progression and viral load in a community outbreak of coronavirus-associated SARS pneumonia: A prospective study. Lancet 2003, 361, 1767-1772. [CrossRef]

27. Wu, Z.; McGoogan, J.M. Characteristics of and Important Lessons from the Coronavirus Disease 2019 (COVID-19) Outbreak in China: Summary of a Report of 72314 Cases from the Chinese Center for Disease Control and Prevention. JAMA 2020, 323, 1239. [CrossRef] [PubMed]

28. Zhou, F.; Yu, T.; Du, R.; Fan, G.; Liu, Y.; Liu, Z.; Xiang, J.; Wang, Y.; Song, B.; Gu, X.; et al. Clinical course and risk factors for mortality of adult inpatients with COVID-19 in Wuhan, China: A retrospective cohort study. Lancet 2020, 395, 1054-1062. [CrossRef]

29. Wu, C.; Chen, X.; Cai, Y.; Xia, J.; Zhou, X.; Xu, S.; Huang, H.; Zhang, L.; Zhou, X.; Du, C.; et al. Risk Factors Associated with Acute Respiratory Distress Syndrome and Death in Patients With Coronavirus Disease 2019 Pneumonia in Wuhan, China. JAMA Intern. Med. 2020. [CrossRef]

30. Henry, B.M.; De Oliveira, M.H.S.; Benoit, S.; Plebani, M.; Lippi, G. Hematologic, biochemical and immune biomarker abnormalities associated with severe illness and mortality in coronavirus disease 2019 (COVID-19): A meta-analysis. Clin. Chem. Lab. Med. 2020. [CrossRef]

31. Deng, Y.; Liu, W.; Liu, K.; Fang, Y.-Y.; Shang, J.; Zhou, L.; Wang, K.; Leng, F.; Wei, S.; Chen, L.; et al. Clinical characteristics of fatal and recovered cases of coronavirus disease 2019 (COVID-19) in Wuhan, China: A retrospective study. Chin. Med. J. 2020. [CrossRef]

32. Guo, T.; Fan, Y.; Chen, M.; Wu, X.; Zhang, L.; He, T.; Wang, H.; Wan, J.; Wang, X.; Lu, Z. Cardiovascular Implications of Fatal Outcomes of Patients with Coronavirus Disease 2019 (COVID-19). JAMA Cardiol. 2020. [CrossRef]

33. Terpos, E.; Ntanasis-Stathopoulos, I.; Elalamy, I.; Kastritis, E.; Sergentanis, T.N.; Politou, M.; Psaltopoulou, T.; Gerotziafas, G.; Dimopoulos, M.A. Hematological findings and complications of COVID -19. Am. J. Hematol. 2020. [CrossRef]

34. Gando, S.; Levi, M.; Toh, C.-H. Disseminated intravascular coagulation. Nat. Rev. Dis. Prim. 2016, 2, 16038. [CrossRef]

35. Wada, H.; Matsumoto, T.; Yamashita, Y. Diagnosis and treatment of disseminated intravascular coagulation (DIC) according to four DIC guidelines. J. Intensiv. Care 2014, 2, 15. [CrossRef] [PubMed]

36. Bick, R.L. Disseminated intravascular coagulation: A review of etiology, pathophysiology, diagnosis, and management: Guidelines for care. Clin. Appl. Thromb. Hemost. 2002, 8, 1-31. [CrossRef] [PubMed]

37. Lillicrap, D. Disseminated intravascular coagulation in patients with 2019-nCoV pneumonia. J. Thromb. Haemost. 2020, 18, 786-787. [CrossRef] [PubMed]

38. Wong, R.S.; Wu, A.; To, K.F.; Lee, N.; Lam, C.W.; Wong, C.K.; Chan, P.K.; Ng, M.H.; Yu, L.M.; Hui, D.S.; et al. Haematological manifestations in patients with severe acute respiratory syndrome: Retrospective analysis. BMJ 2003, 326, 1358-1362. [CrossRef] [PubMed]

39. Yin, S.; Huang, M.; Li, D.; Tang, N. Difference of coagulation features between severe pneumonia induced by SARS-CoV2 and non-SARS-CoV2. J. Thromb. Thrombolysis 2020, 1-4. [CrossRef]

40. Levi, M.; Van Der Poll, T. Coagulation and sepsis. Thromb. Res. 2017, 149, 38-44. [CrossRef]

41. Iba, T.; Levy, J.H.; Raj, A.; Warkentin, T.E. Advance in the Management of Sepsis-Induced Coagulopathy and Disseminated Intravascular Coagulation. J. Clin. Med. 2019, 8, 728. [CrossRef] 
42. Iba, T.; Levy, J.H.; Warkentin, T.E.; Thachil, J.; van der Poll, T.; Levi, M. Scientific and Standardization Committee on DIC, and the Scientific and Standardization Committee on Perioperative and Critical Care of the International Society on Thrombosis and Haemostasis Diagnosis and management of sepsis-induced coagulopathy and disseminated intravascular coagulation. J. Thromb. Haemost. 2019, 17, 1989-1994. [CrossRef]

43. Gupta, N.; Zhao, Y.-Y.; Evans, C.E. The stimulation of thrombosis by hypoxia. Thromb. Res. 2019, 181, 77-83. [CrossRef]

44. Luo, W.; Yu, H.; Gou, J.; Li, X.; Sun, Y.; Li, J.; Liu, L. Clinical Pathology of Critical Patient with Novel Coronavirus Pneumonia (COVID-19). Preprints 2020, 2020, 2020020407.

45. Dolhnikoff, M.; Duarte-Neto, A.N.; de Almeida Monteiro, R.A.; Ferraz Da Silva, L.F.; Pierre de Oliveira, E.; Nascimento Saldiva, P.H.; Mauad, T.; Marcia Negri, E. Pathological evidence of pulmonary thrombotic phenomena in severe COVID-19. J. Thromb. Haemost. 2020. [CrossRef] [PubMed]

46. Marongiu, F.; Grandone, E.; Barcellona, D. Pulmonary thrombosis in 2019-nCoV pneumonia? J. Thromb. Haemost. 2020. [CrossRef] [PubMed]

47. Zhou, X.; Li, Y.; Yang, Q. Antiplatelet Therapy Following Percutaneous Coronary Intervention in Patients Complicated by COVID-19: Implications from Clinical Features to Pathological Findings. Circulation 2020. [CrossRef] [PubMed]

48. Koupenova, M.; Clancy, L.; Corkrey, H.A.; Freedman, J.E. Circulating Platelets as Mediators of Immunity, Inflammation, and Thrombosis. Circ. Res. 2018, 122, 337-351. [CrossRef] [PubMed]

49. Zhang, C.; Shi, L.; Wang, F.S. Liver injury in COVID-19: Management and challenges. Lancet Gastroenterol. Hepatol. 2020, 5, 428-430. [CrossRef]

50. Zhang, Y.; Xiao, M.; Zhang, S.; Xia, P.; Cao, W.; Jiang, W.; Chen, H.; Ding, X.; Zhao, H.; Zhang, H.; et al. Coagulopathy and Antiphospholipid Antibodies in Patients with Covid-19. N. Engl. J. Med. 2020, 382 , e38. [CrossRef]

51. Zulfiqar, A.-A.; Lorenzo-Villalba, N.; Hassler, P.; Andres, E. Immune Thrombocytopenic Purpura in a Patient with Covid-19. N. Engl. J. Med. 2020, 382, e43. [CrossRef]

52. Fox, E.A.; Kahn, S.R. The relationship between inflammation and venous thrombosis. A systematic review of clinical studies. Thromb. Haemost. 2005, 94, 362-365. [CrossRef]

53. Libby, P.; Loscalzo, J.; Ridker, P.M.; Farkouh, M.E.; Hsue, P.Y.; Fuster, V.; Hasan, A.A.; Amar, S. Inflammation, Immunity, and Infection in Atherothrombosis: JACC Review Topic of the Week. J. Am. Coll. Cardiol. 2018, 72, 2071-2081. [CrossRef]

54. Wong, C.K.; Lam, C.W.; Wu, A.K.L.; Ip, W.K.; Lee, N.; Chan, I.H.S.; Lit, L.C.W.; Hui, D.S.; Chan, M.H.M.; Chung, S.S.C.; et al. Plasma inflammatory cytokines and chemokines in severe acute respiratory syndrome. Clin. Exp. Immunol. 2004, 136, 95-103. [CrossRef]

55. Min, C.-K.; Cheon, S.; Ha, N.-Y.; Sohn, K.M.; Kim, Y.; Aigerim, A.; Shin, H.M.; Choi, J.-Y.; Inn, K.-S.; Kim, J.H.; et al. Comparative and kinetic analysis of viral shedding and immunological responses in MERS patients representing a broad spectrum of disease severity. Sci. Rep. 2016, 6, 25359. [CrossRef] [PubMed]

56. Channappanavar, R.; Perlman, S. Pathogenic human coronavirus infections: Causes and consequences of cytokine storm and immunopathology. Semin. Immunopathol. 2017, 39, 529-539. [CrossRef] [PubMed]

57. Jackson, S.P.; Darbousset, R.; Schoenwaelder, S.M. Thromboinflammation: Challenges of therapeutically targeting coagulation and other host defense mechanisms. Blood 2019, 133, 906-918. [CrossRef] [PubMed]

58. Libby, P. The Heart in COVID19: Primary Target or Secondary Bystander? JACC Basic Transl. Sci. 2020. [CrossRef]

59. Qin, C.; Zhou, L.; Hu, Z.; Zhang, S.; Yang, S.; Tao, Y.; Xie, C.; Ma, K.; Shang, K.; Wang, W.; et al. Dysregulation of immune response in patients with COVID-19 in Wuhan, China. Clin. Infect. Dis. 2020. [CrossRef]

60. Liu, J.; Li, S.; Liu, J.; Liang, B.; Wang, X.; Wang, H.; Li, W.; Tong, Q.; Yi, J.; Zhao, L.; et al. Longitudinal characteristics of lymphocyte responses and cytokine profiles in the peripheral blood of SARS-CoV-2 infected patients. medRxiv 2020. preprint. [CrossRef]

61. Clerkin, K.J.; Fried, J.A.; Raikhelkar, J.; Sayer, G.; Griffin, J.M.; Masoumi, A.; Jain, S.S.; Burkhoff, D.; Kumaraiah, D.; Rabbani, L.; et al. Coronavirus Disease 2019 (COVID-19) and Cardiovascular Disease. Circulation 2020, 141, 1648-1655. [CrossRef]

62. Xiong, T.-Y.; Redwood, S.; Prendergast, B.; Chen, M. Coronaviruses and the cardiovascular system: Acute and long-term implications. Eur. Hear J. 2020, 41, 1798-1800. [CrossRef] 
63. Mehta, P.; Mc Auley, D.F.; Brown, M.; Sanchez, E.; Tattersall, R.S.; Manson, J.J. COVID-19: Considercytokinestorm syndromes and immunosuppression. Lancet 2020. [CrossRef]

64. Siddiqi, H.K.; Mehra, M.R. COVID-19 illness in native and immunosuppressed states: A clinical-therapeutic staging proposal. J. Hear Lung Transpl. 2020, 39, 405-407. [CrossRef]

65. Ramacciotti, E.; Agati, L.B.; Aguiar, V.C.R.; Wolosker, N.; Guerra, J.C.; De Almeida, R.P.; Alves, J.C.; Lopes, R.D.; Wakefield, T.W.; Comerota, A.J.; et al. Zika and Chikungunya Virus and Risk for Venous Thromboembolism. Clin. Appl. Thromb. Hemost. 2019, 25. [CrossRef] [PubMed]

66. Smither, S.J.; O’Brien, L.M.; Eastaugh, L.; Woolley, T.; Lever, M.; Fletcher, T.; Parmar, K.; Hunt, B.J.; Watts, S.; Kirkman, E.; et al. Haemostatic Changes in Five Patients Infected with Ebola Virus. Viruses 2019, 11, 647. [CrossRef] [PubMed]

67. Tisoncik, J.R.; Korth, M.J.; Simmons, C.P.; Farrar, J.; Martin, T.R.; Katze, M.G. Into the eye of the cytokine storm. Microbiol. Mol. Biol. Rev. 2012, 76, 16-32. [CrossRef] [PubMed]

68. Sardu, C.; Gambardella, J.; Morelli, M.B.; Wang, X.; Marfella, R.; Santulli, G. Is COVID-19 an Endothelial Disease? Clinical and Basic Evidence. Preprints 2020, 2020040204. [CrossRef]

69. Escher, R.; Breakey, N.; Lämmle, B. Severe COVID-19 infection associated with endothelial activation. Thromb. Res. 2020, 190, 62. [CrossRef] [PubMed]

70. Varga, Z.; Flammer, A.J.; Steiger, P.; Haberecker, M.; Andermatt, R.; Zinkernagel, A.S.; Mehra, M.R.; Schuepbach, R.A.; Ruschitzka, F.; Moch, H. Endothelial cell infection and endotheliitis in COVID-19. Lancet 2020, 395, 1417-1418. [CrossRef]

71. Hamming, I.; Timens, W.; Bulthuis, M.; Lely, A.T.; Navis, G.; Van Goor, H. Tissue distribution of ACE2 protein, the functional receptor for SARS coronavirus. A first step in understanding SARS pathogenesis. J. Pathol. 2004, 203, 631-637. [CrossRef]

72. Song, J.; Hu, B.; Qu, H.; Wang, L.; Huang, X.; Li, M.; Zhang, M. Upregulation of angiotensin converting enzyme 2 by shear stress reduced inflammation and proliferation in vascular endothelial cells. Biochem. Biophys. Res. Commun. 2020. [CrossRef]

73. Takei, Y.; Yamada, M.; Saito, K.; Kameyama, Y.; Sugiura, H.; Makiguchi, T.; Fujino, N.; Koarai, A.; Toyama, H.; Saito, K.; et al. Increase in circulating ACE-positive endothelial microparticles during acute lung injury. Eur. Respir. J. 2019, 54, 1801188. [CrossRef]

74. Grasselli, G.; Zangrillo, A.; Zanella, A.; Antonelli, M.; Cabrini, L.; Castelli, A.; Cereda, D.; Coluccello, A.; Foti, G.; Fumagalli, R.; et al. COVID-19 Lombardy ICU Network. Baseline Characteristics and Outcomes of 1591 Patients Infected With SARS-CoV-2 Admitted to ICUs of the Lombardy Region, Italy. JAMA 2020, 323, 1574. [CrossRef]

75. Xie, J.; Covassin, N.; Fan, Z.; Singh, P.; Gao, W.; Li, G.; Kara, T.; Somers, V.K. Association Between Hypoxemia and Mortality in Patients With COVID-19. Mayo Clin. Proc. 2020. [CrossRef] [PubMed]

76. Mo, P.; Xing, Y.; Xiao, Y.; Deng, L.; Zhao, Q.; Wang, H.; Xiong, Y.; Cheng, Z.; Gao, S.; Liang, K.; et al. Clinical characteristics of refractory COVID-19 pneumonia in Wuhan, China. Clin. Infect. Dis. 2020. [CrossRef] [PubMed]

77. Gattinoni, L.; Chiumello, D.; Rossi, S. COVID-19 pneumonia: ARDS or not? Crit. Care 2020, $24,154$. [CrossRef] [PubMed]

78. Xu, Z.; Shi, L.; Wang, Y.; Zhang, J.; Huang, L.; Zhang, C.; Liu, S.; Zhao, P.; Liu, H.; Zhu, L.; et al. Pathological findings of COVID-19 associated with acute respiratory distress syndrome. Lancet Respir. Med. 2020, 8, 420-422. [CrossRef]

79. Fox, S.E.; Akmatbekov, A.; Harbert, J.L.; Li, G.; Quincy Brown, J.; Vander Heide, R.S. Pulmonary and Cardiac Pathology in Covid-19: The First Autopsy Series from New Orleans. medRxiv 2020. [CrossRef]

80. Ranucci, M.; Ballotta, A.; Di Dedda, U.; Bayshnikova, E.; Dei Poli, M.; Resta, M.; Falco, M.; Albano, M.; Albano, G.; Menicanti, L. The procoagulant pattern of patients with COVID-19 acute respiratory distress syndrome. J. Thromb. Haemost. 2020. [CrossRef]

81. Chong, P.Y.; Chui, P.; Ling, A.E.; Franks, T.J.; Tai, D.Y.; Leo, Y.S.; Kaw, G.J.; Wansaicheong, G.; Chan, K.P.; Ean Oon, L.L.; et al. Analysis of deaths during the severe acute respiratory syndrome (SARS) epidemic in Singapore: Challenges in determining a SARS diagnosis. Arch. Pathol. Lab. Med. 2004, 128, 195-204. 
82. Obi, A.T.; Tignanelli, C.J.; Jacobs, B.N.; Arya, S.; Park, P.K.; Wakefield, T.W.; Henke, P.K.; Napolitano, L.M. Empirical systemic anticoagulation is associated with decreased venous thromboembolism in critically ill influenza A H1N1 acute respiratory distress syndrome patients. J. Vasc. Surg. Venous Lymphat. Disord. 2019, 7,317-324. [CrossRef]

83. Wang, T.; Chen, R.; Liu, C.; Liang, W.; Guan, W.; Tang, R.; Tang, C.; Zhang, N.; Zhong, N.; Li, S. Attention should be paid to venous thromboembolism prophylaxis in the management of COVID-19. Lancet Haematol. 2020, 7, e362-e363. [CrossRef]

84. Zhang, L.; Zhu, F.; Xie, L.; Wang, C.; Wang, J.; Chen, R.; Jia, P.; Guan, H.Q.; Peng, L.; Chen, Y.; et al. Clinical characteristics of COVID-19-infected cancer patients: A retrospective case study in three hospitals within Wuhan, China. Ann. Oncol. 2020. [CrossRef]

85. Danzi, G.B.; Loffi, M.; Galeazzi, G.; Gherbesi, E. Acute pulmonary embolism and COVID-19 pneumonia: A random association? Eur. Hear. J. 2020, 41, 1858. [CrossRef] [PubMed]

86. Xie, Y.; Wang, X.; Yang, P.; Zhang, S. COVID-19 Complicated by Acute Pulmonary Embolism. Radiol. Cardiothorac. Imaging 2020, 2, e200067. [CrossRef]

87. Chen, J.; Wang, X.; Zhang, S.; Liu, B.; Wu, X.; Wang, Y.; Wang, X.; Yang, M.; Sun, J.; Xie, Y. Findings of Acute Pulmonary Embolism in COVID-19 Patients. SSRN Electron. J. 2020. [CrossRef]

88. Cui, S.; Chen, S.; Li, X.; Liu, S.; Wang, F. Prevalence of venous thromboembolism in patients with severe novel coronavirus pneumonia. J. Thromb. Haemost. 2020. [CrossRef] [PubMed]

89. Klok, F.A.; Kruip, M.; Van Der Meer, N.; Arbous, M.S.; Gommers, D.; Kant, K.; Kaptein, F.; Van Paassen, J.; Stals, M.; Huisman, M.; et al. Incidence of thrombotic complications in critically ill ICU patients with COVID-19. Thromb. Res. 2020. [CrossRef]

90. Helms, J.; Tacquard, C.; Severac, F.; Leonard-Lorant, I.; Ohana, M.; Delabranche, X.; Merdji, H.; Clere-Jehl, R.; Schenck, M.; Fagot Gandet, F.; et al. High risk of thrombosis in patients in severe SARS-CoV-2 infection: A multicenter prospective cohort study. Intensiv. Care Med. 2020, 1-10. [CrossRef]

91. Wada, H.; Thachil, J.; Di Nisio, M.; Mathew, P.; Kurosawa, S.; Gando, S.; Kim, H.; Nielsen, J.; Dempfle, C.-E.; Levi, M.; et al. Guidance for diagnosis and treatment of DIC from harmonization of the recommendations from three guidelines. The Scientific Standardization Committee on DIC of the International Society on Thrombosis Haemostasis. J. Thromb. Haemost. 2013, 11, 761-767. [CrossRef]

92. Tang, N.; Bai, H.; Chen, X.; Gong, J.; Li, D.; Sun, Z. Anticoagulant treatment is associated with decreased mortality in severe coronavirus disease 2019 patients with coagulopathy. J. Thromb. Haemost. 2020, 18, 1094-1099. [CrossRef]

93. Alexander, G.C.; Qato, D.M. Ensuring Access to Medications in the US During the COVID-19 Pandemic. JAMA 2020. [CrossRef]

94. Poterucha, T.J.; Libby, P.; Goldhaber, S.Z. More than an anticoagulant: Do heparins have direct anti-inflammatory effects? Thromb. Haemost. 2017, 117, 437-444. [CrossRef]

95. Shi, C.; Wang, C.; Wang, H.; Yang, C.; Cai, F.; Zeng, F.; Cheng, F.; Liu, Y.; Zhou, T.; Deng, B.; et al. The potential of low molecular weight heparin to mitigate cytokine storm in severe COVID-19 patients: A retrospective clinical study. medRxiv 2020. [CrossRef]

96. Shukla, D.; Spear, P.G. Herpesviruses and heparan sulfate: An intimate relationship in aid of viral entry. J. Clin. Investig. 2001, 108, 503-510. [CrossRef] [PubMed]

97. Ghezzi, S.; Cooper, L.; Rubio, A.; Pagani, I.; Capobianchi, M.R.; Ippolito, G.; Pelletier, J.; Meneghetti, M.C.Z.; Lima, M.A.; Skidmore, M.A.; et al. Heparin prevents Zika virus induced-cytopathic effects in human neural progenitor cells. Antivir. Res. 2017, 140, 13-17. [CrossRef] [PubMed]

98. Sanders, J.M.; Monogue, M.L.; Jodlowski, T.Z.; Cutrell, J.B. Pharmacologic Treatments for Coronavirus Disease 2019 (COVID-19) A Review. JAMA 2020. [CrossRef]

99. Thachil, J. The versatile heparin in COVID-19. J. Thromb. Haemost. 2020, 18, 1020-1022. [CrossRef]

100. Gibson, C.M.; Spyropoulos, A.C.; Cohen, A.T.; Hull, R.D.; Goldhaber, S.Z.; Yusen, R.D.; Hernandez, A.F.; Korjian, S.; Daaboul, Y.; Gold, A.; et al. The IMPROVEDD VTE risk score: Incorporation of D-dimer into the IMPROVE score to improve venous thromboembolism risk stratification. TH Open 2017, 1, e56-e65. [CrossRef]

101. Cohen, A.T.; Alikhan, R.; Arcelus, J.; Bergmann, J.-F.; Haas, S.; Merli, G.J.; Spyropoulos, A.C.; Tapson, V.F.; Turpie, A.G.G. Assessment of venous thromboembolism risk and the benefits of thromboprophylaxis in medical patients. Thromb. Haemost. 2005, 94, 750-759. [CrossRef] 
102. Cohen, A.T.; Harrington, R.A.; Goldhaber, S.Z.; Hull, R.D.; Wiens, B.L.; Gold, A.; Hernandez, A.F.; Gibson, C.M. Extended Thromboprophylaxis with Betrixaban in Acutely Ill Medical Patients. N. Engl. J. Med. 2016, 375, 534-544. [CrossRef]

103. Goldhaber, S.Z.; Leizorovicz, A.; Kakkar, A.K.; Haas, S.; Merli, G.; Knabb, R.M.; Weitz, J.I. Apixaban versus enoxaparin for thromboprophylaxis in medically ill patients. N. Engl. J. Med. 2011, 365, 2167-2177. [CrossRef]

104. Spyropoulos, A.C.; Ageno, W.; Albers, G.W.; Elliott, C.G.; Halperin, J.L.; Hiatt, W.R.; Maynard, G.A.; Steg, P.G.; Weitz, J.I.; Suh, E.; et al. Rivaroxaban for Thromboprophylaxis after Hospitalization for Medical Illness. N. Engl. J. Med. 2018, 379, 1118-1127. [CrossRef]

105. Wang, J.; Hajizadeh, N.; Moore, E.E.; McIntyre, R.C.; Moore, P.K.; Veress, L.A.; Yaffe, M.B.; Moore, H.B.; Barrett, C.D. Tissue Plasminogen Activator (tPA) Treatment for COVID-19 Associated Acute Respiratory Distress Syndrome (ARDS): A Case Series. J. Thromb. Haemost. 2020. [CrossRef] [PubMed]

106. Lighter, J.; Phillips, M.; Hochman, S.; Sterling, S.; Johnson, D.; Francois, F.; Stachel, A. Obesity in patients younger than 60 years is a risk factor for Covid-19 hospital admission. Clin. Infect. Dis. 2020, ciaa415. [CrossRef] [PubMed]

107. Simonnet, A.; Chetboun, M.; Poissy, J.; Raverdy, V.; Noulette, J.; Duhamel, A.; Labreuche, J.; Mathieu, D.; Pattou, F.; Jourdain, M.; et al. High prevalence of obesity in severe acute respiratory syndrome coronavirus-2 (SARS-CoV-2) requiring invasive mechanical ventilation. Obsity 2020. [CrossRef] [PubMed]

108. Barrasa, H.; Rello, J.; Tejada, S.; Martín, A.; Balziskueta, G.; Vinuesa, C.; Fernández-Miret, B.; Villagra, A.; Vallejo, A.; Sebastián, A.S.; et al. Alava COVID19 Study Investigators. SARS-Cov-2 in Spanish Intensive Care: Early Experience with 15-day Survival in Vitoria. Anaesth. Crit. Care Pain Med. 2020. [CrossRef] [PubMed]

109. Venkata, C.; Sampathkumar, P.; Afessa, B. Hospitalized patients with 2009 H1N1 influenza infection: The Mayo Clinic experience. Mayo Clin. Proc. 2010, 85, 798-805. [CrossRef]

110. Morel, O.; Luca, F.; Grunebaum, L.; Jesel, L.; Meyer, N.; Desprez, D.; Robert, S.; Dignat-George, F.; Toti, F.; Simon, C.; et al. Short-term very low-calorie diet in obese females improves the haemostatic balance through the reduction of leptin levels, PAI-1 concentrations and a diminished release of platelet and leukocyte-derived microparticles. Int. J. Obes. 2011, 35, 1479-1486. [CrossRef]

111. Badimon, L.; Bugiardini, R.; Cenko, E.; Cubedo, J.; Dorobantu, M.; Duncker, D.J.; Estruch, R.; Miličić, D.; Tousoulis, D.; Vasiljevic, Z.; et al. Position Paper of the European Society of Cardiology working group of coronary pathophysiology and microcirculation: Obesity and heart disease. Eur. Hear J. 2017, 38, 1951-1958. [CrossRef]

112. Caër, C.; Rouault, C.; Le Roy, T.; Poitou, C.; Aron-Wisnewsky, J.; Torcivia, A.; Bichet, J.-C.; Clément, K.; Guerre-Millo, M.; André, S. Immune cell-derived cytokines contribute to obesity related inflammation, fibrogenesis and metabolic deregulation in human adipose tissue. Sci. Rep. 2017, 7, 3000. [CrossRef]

113. Morel, O.; Jesel, L.; Freyssinet, J.-M.; Toti, F. Cellular mechanisms underlying the formation of circulating microparticles. Arter. Thromb. Vasc. Biol. 2011, 31, 15-26. [CrossRef]

114. Amabile, N.; Cheng, S.; Renard, J.M.; Larson, M.G.; Ghorbani, A.; McCabe, E.; Griffin, G.; Guerin, C.; Ho, J.E.; Shaw, S.Y.; et al. Association of circulating endothelial microparticles with cardiometabolic risk factors in the Framingham Heart Study. Eur. Hear J. 2014, 35, 2972-2979. [CrossRef]

115. Abbas, M.; Jesel, L.; Auger, C.; Amoura, L.K.; Messas, N.; Manin, G.; Rumig, C.; León-González, A.J.; Ribeiro, T.P.; Silva, G.C.; et al. Endothelial Microparticles From Acute Coronary Syndrome Patients Induce Premature Coronary Artery Endothelial Cell Aging and Thrombogenicity: Role of the Ang II/AT1 Receptor/NADPH Oxidase-Mediated Activation of MAPKs and PI3-Kinase Pathways. Circulation 2017, 135, 280-296. [CrossRef] [PubMed]

116. Mack, M.; Kleinschmidt, A.; Brühl, H.; Klier, C.; Nelson, P.J.; Cihak, J.; Plachý, J.; Stangassinger, M.; Erfle, V.; Schlöndorff, D. Transfer of the chemokine receptor CCR5 between cells by membrane-derived microparticles: A mechanism for cellular human immunodeficiency virus 1 infection. Nat. Med. 2000, 6, 769-775. [CrossRef] [PubMed]

117. Wang, J.; Chen, S.; Bihl, J. Exosome-Mediated Transfer of ACE2 (Angiotensin-Converting Enzyme 2) from Endothelial Progenitor Cells Promotes Survival and Function of Endothelial Cell. Oxidative Med. Cell. Longev. 2020, 2020, 4213541-11. [CrossRef] [PubMed]

118. Lóczi, L.; Kappelmayer, J.; Tarr, T.; Bagoly, Z. Antiphospholipid syndrome and the risk of myocardial infarction: Current evidence and uncertainties. Kardiol. Polska 2019, 78, 6-14. [CrossRef] 
119. Mobarrez, F.; Gunnarsson, I.; Svenungsson, E. Altered $\beta 2$ glycoprotein I expression on microparticles in the presence of antiphospholipid antibodies. J. Thromb. Haemost. 2017, 15, 1799-1806. [CrossRef]

120. Nomijra, S.; Komiyama, Y.; Kokawa, T.; Takahashi, H.; Koike, T.; Matsuura, E. Binding of beta2-glycoprotein I to platelet-derived microparticles. Br. J. Haematol. 2008, 85, 639. [CrossRef]

121. Gralinski, L.E.; Sheahan, T.P.; Morrison, T.E.; Menachery, V.D.; Jensen, K.; Leist, S.R.; Whitmore, A.; Heise, M.T.; Baric, R.S.; Enjuanes, L.; et al. Complement Activation Contributes to Severe Acute Respiratory Syndrome Coronavirus Pathogenesis. mBio 2018, 9. [CrossRef]

122. Campbell, C.M.; Kahwash, R. Will Complement Inhibition be the New Target in Treating COVID-19 Related Systemic Thrombosis? Circulation 2020. [CrossRef]

(C) 2020 by the authors. Licensee MDPI, Basel, Switzerland. This article is an open access article distributed under the terms and conditions of the Creative Commons Attribution (CC BY) license (http://creativecommons.org/licenses/by/4.0/). 